\title{
Physical Education and Sports in the Reports of Foreigner Education Experts Coming to Turkey in the Period of Republic (1923-1960)
}

\author{
Mehmet Yildiz*, Özbay Güven \\ Physical Education and Sports Teaching Department, Faculty of Sports Sciences, Gazi University, Turkey
}

Copyright $\bigcirc 2018$ by authors, all rights reserved. Authors agree that this article remains permanently open access under the terms of the Creative Commons Attribution License 4.0 International License

\begin{abstract}
Different applications have been initiated for the restructuring of the Turkish education System, with the proclamation of the Republic and 123 training experts have been invited to Turkey between the years 1923-1960 in this regard. 19 people have been requested to prepare the report in relation with their fields of specialization among the foreign education experts arriving in Turkey between these dates; however, these experts have produced reports that include the whole of the Turkish education system. This situation has also led to superficial assessment of some issues that need to be addressed specially. The physical education and sports field, which is one of these areas, is handled very superficially in the expert reports, even they have seen to be affected from the reports carried out before themselves and their reports are in the situational dimension rather than functionality. As there is no adequate development in the field of physical education and sports within the reformed education system, the Republic of Turkey has taken measures to bring foreign physical education and sports experts to Turkey through government agencies such as Turkey Training Community Alliance (TTCA), Turkish Sports Authority, the General Directorate of Physical Education and to develop this field in modern sense.
\end{abstract}

Keywords Foreign Education Expert, Report, Physical Education and Sports

\section{Introduction}

The concept of westernization in Turkey emerged with the proclamation of the Republic showed itself in different ways. Students have been sent outside Turkey as a continuation of ideas for recognition on site Science; receiving on-site education seeing the practices on site and carrying thereof in Turkey for the benefit of Turkey and various reports on the systems of other countries has been requested. Moreover, Turkey, the Ministry of Education has requested some successful instructors to examine by sending them abroad and to submit the results. The works on education published in developed countries were translated into Turkish and thereby western education system has been tried to be promoted with the books in Turkey [1].

As well as students and instructors have been sent from Turkey to abroad, foreign experts have been invited to Turkey in different branches including also the field of education in order to solve the problems of development of the newly established Republic of Turkey with the proclamation of Republic [1]. A total of 123 foreign education specialists came to Turkey between the years 1923-1960 for various purposes such as giving lectures, teaching, presenting reports [2]. It is the period that the establishment of a new Turkish State to be described as the first period of foreign experts, who were invited to Turkey has been realized, that the institutions have been tried to fall into place, that revolutions have been done, the system has been tried to be created all over again, and the education specialists coming from this period consist of education experts from Germany, Belgium, France, Austria, Sweden, Switzerland, Hungary, Czechoslovakia, United Kingdom, Yugoslavia and USA. During this period, it is not possible to say that experts have sufficient time from Turkey. Experts who came for a short period of time, usually two months, tried to make a report and make suggestions through Translators [1]. Education experts coming to Turkey between 1950 and 1960 which is the second period have not stayed a long time in Turkey as well. However, unlike from the education experts coming to Turkey in the first period, they usually conducted on-site investigation, interviews and questionnaires. Thus they had a chance to obtain more concrete data and presented more detailed proposals. In the study areas, they have observed the claims of the education practitioners organizing 
conferences, interviews, seminars and panels. These experts clarified their proposals by organizing concrete and detailed reports that were limited to the field they were invited to specialize [1]. The majority of foreign education experts are Americans who came to Turkey in the second period. The main objective of the preference of these experts is to develop as soon as possible by using experienced trainers and reach the goal with minimum error margin [3].

\section{Material and Methods}

Document analysis was used in the analysis and interpretation of this research in qualitative research methods. This technique, which Duverger [4] called "documentary observation", is described by Rummel [5] as the "document method". Document analysis includes analysis of written materials that contain information about the facts or phenomena targeted to be investigated [6].

The reports published by the Ministry of National Education as Turkish and submitted by the education experts to the Republic of Turkey have formed the main source of the study. Moreover, it has been benefited from the General Directorate of State Archives, of the Republic of Turkey, Decrees of the Council of Ministers of the Republic of Turkey, and periodical publications. Graduate and doctoral dissertations were also used in this field during the data collection process.

In qualitative studies, content analysis is used in the analysis of the documents [7].Content analysis is a form of interpretation that provides a proper, quantitatively accurate generalization of the construction and classification of meaningful meanings in order to reveal the common aspects of many textual content [8]. In this context, 15 different codes were formed in 4 different categories and necessary evaluations were made.

\section{Validity and Reliability}

The ability to provide validity in content analysis depends on the consistency between the objectives and tools of the research $[8,9]$. In content analysis, there are no validity measurement tools other than the definitions of the categories. Therefore, in content analysis, the definitions of the categories should be publicly identifiable and well defined. Reliability is provided especially by the coding system and the category system. The most important sign of reliability in this context is the creation of the category system and the explicit identification of each category [8].Determination of the categories has been provided based on the theoretical structural in order to ensure the validity and reliability of this research carried out in this context. The categories and encodings generated in the data analysis process were made independent of one another by a researcher other than the researcher, and then the generated codes and categories were compared thereafter.

\section{Results}

123 foreign education experts visited Turkey between the years 1923-1960 have done studies in the field of education. While some of these specialists were preparing reports, some gave conferences and some came for education.

Table 1. Distribution of Foreign Education Experts Coming to Turkey between the Years of 1923-1960 According to the Countries [10]

\begin{tabular}{|c|c|}
\hline Country Name & Total \\
\hline USA & 48 \\
\hline Germany & 14 \\
\hline Belgium & 14 \\
\hline France & 14 \\
\hline Austria & 8 \\
\hline Hungary & 4 \\
\hline Swiss & 3 \\
\hline Britain & 2 \\
\hline Swedish & 2 \\
\hline Czechoslovakia & 1 \\
\hline Yugoslavia & 1 \\
\hline Unknown & 12 \\
\hline Total & 123 \\
\hline
\end{tabular}

19 education experts out of 123 foreign education experts coming to Turkey between the years of 1923-1960 have prepared reports on Turkish education system. Foreign education experts who prepare reports on the Turkish education system are as follows. 
Table 2. Foreign Experts Preparing the Report to the Turkish Government between 1923-1960 [1]

\begin{tabular}{|c|c|c|c|}
\hline Serial & Year & Name and Surname & Report Name \\
\hline 1 & 1924 & John Dewey & Report on the Ministry of Education of Turkey \\
\hline 2 & 1924 & Paul Monreo & How should the first schools be reformed? \\
\hline 3 & 1925 & Alfred Kühne & Report On Development of Occupational Education \\
\hline 4 & 1926 & George Stiehler & Report On Art Education \\
\hline 5 & 1926 & Frey & Report on Handcrafts, Business Schools and Teaching \\
\hline 6 & 1927 & Omer Buyse & Report on Technical Teaching \\
\hline 7 & 1928 & Adolphe Ferrière & Report on Business School \\
\hline 8 & 1933 & Amerikan Heyeti & Report on Education Affairs \\
\hline 9 & 1934 & Berly Parker & Report on First Education in Turkey \\
\hline 10 & 1951 & Watson Dickerman & Report on Civic Education in Turkey \\
\hline 11 & 1951 & John J. Rufi & Secondary Education in Turkey, Observations, Problems and Advices \\
\hline 12 & 1951 & Kate Vixon Wofford & Report on the Village Primary School in Turkey \\
\hline 13 & 1952 & Lester Beals & Report on the Need for Guidance \\
\hline 14 & 1952 & Ellsworth Tompkins & $\begin{array}{l}\text { Organization, Administration and Inspection in Secondary Schools of the } \\
\text { Republic of Turkey }\end{array}$ \\
\hline 15 & 1953 & Roben J. Maaske & Report on Teacher Training in Turkey \\
\hline 16 & 1955 & M. Costat & Report on the Vocational School in Turkey \\
\hline 17 & 1955 & Elizabeth S. Gorvine & Assessment of Girl Technical Education Programs and Proposals \\
\hline 18 & 1957 & $\begin{array}{l}\text { ICA (American Economic Aid } \\
\text { Organization) }\end{array}$ & $\begin{array}{l}\text { Reports of the Current Situation of Commercial Education in Turkey and } \\
\text { Required Changes }\end{array}$ \\
\hline 19 & 1957 & J. Orizet & Vocational and Technical Education Schools \\
\hline
\end{tabular}

While most of the 19 mentioned experts were preparing reports on vocational and technical education, only three experts had superficially addressed on physical education and sport in their reports. These experts are John Dewey, Berly Parker and Roben J. Maaske [10].

\section{Physical Education and Sports in John Dewey's "Report on the Ministry of Education"}

John Dewey was the first foreign experts invited to Turkey. He is a professor at Columbia University. John Dewey, which is one of the pioneers of philosophy, was invited to Turkey in 1923 with a letter. John Dewey, who came to Turkey in 1924 with his wife, left Turkey the same year in mid-September. John Dewey, who came to Turkey has made examination with regard to the education system in Ankara and Istanbul for two months, and has submitted two reports to the Ministry of Education. The first report concerns the allowances that need to be placed on the budget. He did not write the second report in Turkey and sent it by completing in America. These reports were combined for the first time and published in 1939 [11].

John Dewey stressed in his second report that reform cannot be done without facilitating the teachers' possibilities in terms of both general knowledge and vocational education methods that he gave opinion on principles, methods and recommendations to ensure the developments of the teacher who are on duty [12].

There is an opinion of John Dewey that courses to train teachers such as physical training, sports and health information, kindergartens, music, painting, sewing with commerce and industrial schools in Some teacher schools" in "c article" of the title of "Training Teacher" of the report on the Ministry of Education of Turkey must be placed [12].Dewey has given advice for training physical education teachers with this view.

John Dewey also stated in his report that "The school gardens are not only for physical training of the students and doing sports, but also are vast and important so as to be a center for people to have fun and to do sports, that physical training, sports and play are very important in foreign countries, and that these issues should be emphasized [12].

\section{Physical Education and Sports in Berly Parker's "Report on First Education in Turkey"}

Berly Parker came to Turkey with the advice of John Dewey had worked as a consultant in Ankara College of Turkish Education Association for two years, then he was appointed to make examination in the primary schools by the Ministry of Education in Turkey. American educator Prof. Dr. Berly Parker made observations, evaluating the Turkish education system on a total of 100 separate schools. Beryl Parker has submitted school, student, teacher, course schedules and recommendations of primary schools in Turkey in the form of report to the Ministry of Board of Education of Turkey [13]. While Berly Parker is stating in 
his report that "among the most needed courses for organizing as a curriculum is a physical education course, he has addressed that there are problem in relation to the lack of necessary physical education course areas, and the implementation of the physical education course"[10].

Parker has also stated that the necessity of going to a remote and more functional application from the bureaucracy in the physical education with the idea of " as a role for primary schools to address the needs of the Turkish people," a proper job would be made if health education or physical education formalities remain "[13].

\section{Physical Education and Sports in Roben J. Maaske's "Report on Teacher Training in Turkey"}

USA Oregon Teacher College Rector Professor in Ordinary Roben J. Maaske, who came to Turkey upon the invitation of the Board of Education in 1953, made investigations in Turkey in January-March period. During his investigations, he visited a total of 63 institutions, where educational institutions are located, including four teacher education schools, six village institutes, two educational institutes, two universities, technical school, primary school, junior high school, high school and so on in İstanbul, Ankara, İzmir, Adana, Konya and Bolu, and presented about 45 speeches and seminars on teacher training and on-the-job training. He participated in the fifth National Education Council and presented his proposals as a report to the Ministry of Board of Education. Roben J. Maaske think in his report that "Primary school teachers are not being educated enough to teach children in Physical education courses. Teachers who teach these courses in Teaching schools should address their programs in a way that meets the needs of primary school teachers. "In Roben J. Maaske's report, he also emphasized that "Teachers are inadequate for physical education classes and that this situation must be taken into consideration in teaching schools. There is also no closed training room at Village Institutes." He presents an opinion that "A combined meeting and a physical education room for student recreational activities such as concerts, conferences etc. at each village institute should be built." [14].

In general, Maaske lie down and set out the principles to be followed to train good teachers in primary, secondary and higher education, especially in teacher schools and village institutes.

\section{Effects of Foreign Expert Reports on Turkish Physical Education and Sport System}

The reports of foreign experts did not immediately affect the field of physical education and sports as in the Turkish national education system; it can be said that the regulations related to the issues that foreign experts have mentioned in the reports are included in the National Education Councils, which have been held at certain time intervals starting from 1939 until 2014 and in which the problems of the Turkish national education system were addressed in detail, and which aimed at finding solutions to these problems. Some of these arrangements are as follows:

In the third National Education Council, held between 2 and 10 December 1946, the following decisions are taken that "Providing playgrounds for children in the age of compulsory education is one of the subjects that the school family unions will dwell on it continuously. The youths of village should be encouraged to take advantage of the playground of the school in the villages". [15] This decision taken by the Third National Education Council is in line with John Dewey's proposal for the use of school gardens and is considered to be influential on the decisions taken.

In the third National Education Council, held between 2-10 December 1946, In the "Girls Institutes Curriculum Programs" department, increasing the number of gym class hours has been accepted by commission [15].In the fourth National Education Council held between 23-32 August 1949 , it was proposed to distribute physical education to 4 academic year in high schools, in pursuant to the report of the coordinating committee established for increasing high schools to four years, in this regard, reorganization of physical education course hours in high school was accepted by the commission [16].In the sixth National Education Council held between 18-23 March 1957, the curriculum programs of the technical education schools have been rearranged and the addition of the physical education course into the curriculum has been decided [17]. These decisions draw attention as the decisions taken in the same direction with the relevant views with the physical education course curriculum that is mentioned in the reports of foreign education experts and that is deemed necessary to be arranged mostly.

Reports of Foreigner Education Experts do not benefit adequately because this reports are taken seriously by Turkish authorized. Now, some important educational issues mentioned in this report are still valid and Turkish authorized work to find solutions.

\section{Conclusions}

Although foreign education experts are invited to Turkey for different purposes, research results have revealed that they have included similar issues in their reports. In this period, in addition, these specialists have not included religious education, education of private schools and of children with disabilities, which are part of this education. In this respect, many of the main themes of education that need to be taken care of are either completely out of the reports or dealt with very superficially. In this context, the field of physical education and sports is very superficial in the reports of only three 
experts. It is very noteworthy that there is such backwardness in the expert reports of the physical education and sports field which is a very important element in the upbringing of youth in such period that newly education system of young Republic of Turkey is shaped. In addition, some specialists have been advised of different issues, even though they do not become specialized. This situation has been interpreted by Turkish educators as intervention to expert reports. However, Turkey has not benefited sufficiently from the reports. These reports have not been taken seriously by the authorities who have had a say in the development of Turkish education. Therefore, the Republic of Turkey seeks to realize the development move needed in the field of physical education and sports, by inviting, physical education teachers, coaches, technical directors, conditioner and experts to Turkey through official sports organizations.

\section{REFERENCES}

[1] Şahin, M. Türkiye'de Öğretmen Yetiştirme Uygulamalarında Yabancı Uzmanların Yeri. Doktora Tezi, Dokuz Eylül Üniversitesi. Atatürk İlkeleri ve İnkılâp Tarihi Enstitüsü, İzmir, 1996.

[2] Ergün, M. Atatürk Devri Türk Eğitimi. Ankara: Ankara Üniversitesi Basımevi, 1982.

[3] Çakır, T. Cumhuriyet'in Yirmi Beşinci Yılı'nda Türk Milli Eğitiminde ilköğretim. Yüksek Lisans Tezi, Sakarya Üniversitesi. Sosyal Bilimler Enstitüsü, Sakarya, 1999.

[4] Duverger, M. Sosyal Bilimlere Giriş: Metodoloji Açısından, Çev: Unsal Oskay. Ankara: Bilgi Yayınevi, 1973.

[5] Rummel, J. F. An Introduction to Research Procedures in
Education SecondEdition. Harper and Row, 1964.

[6] Madge, J. The Tools of Science an Analytical Description of Social Science Techniques. Anchor Books Doubleday and Comp., 1965 Gökçe, O. İçerik analizi: Kuramsal ve pratik bilgiler. Ankara: Siyasal Kitabevi, 2006.

[7] Merriam, S. Qualitative research and case study applications in education. Revised and expanded from case study research in education. USA: JB Printing, 1998.

[8] Gökçe, O. İçerik analizi: Kuramsal ve pratik bilgiler. Ankara: Siyasal Kitabevi, 2006.

[9] Bilgin, N. Sosyal bilimlerde içerik analizi. Teknikler ve örnek çalışmalar. Ankara: Siyasal Kitabevi, 2006.Merriam, S. Qualitative research and case study applications in education. Revised and expanded from case study research in education. USA: JB Printing, 1998.

[10] Sulubulut, M. Eğitim Alanında Türkiye'ye Davet Edilen Yabanc1 Uzmanlar (1923-1960). Yüksek Lisans Tezi, Ahi Evran Üniversitesi. Sosyal Bilimler Enstitüsü, Kırşehir, 2014.

[11] Bal, H. 1924 Raporunun Türk Eğitimine Etkileri ve John Dewey'in Eğitim Felsefesi. İstanbul: Aydınlar Matbaası, 1991.

[12] Dewey, J. Türkiye Maarif Hakkında Rapor. İstanbul: Maarif Vekilliği Devlet Basımevi, 1939.

[13] Parker, B. Türkiye'de İlk Tahsil Hakkında Rapor. İstanbul: Maarif Vekilliği Devlet Basımevi, 1939.

[14] Maaske, R. J. Türkiye'de Öğretmen Yetiştirme Hakkında Rapor. Ankara, 1956.

[15] 3rd National Education Counsel Book. Ankara: General Secretariat of the State Council, 1946.

[16] 4th National Education Counsel Book. Ankara: General Secretariat of the State Council, 1949.

[17] 6th National Education Counsel Book. Ankara: General Secretariat of the State Council, 1957. 